\title{
Impact of postpartum milking frequency on the immune system and the blood metabolite concentration of dairy cows ${ }^{1}$
}

\author{
M. C. Loiselle, ${ }^{*}$ C. Ster,† B. G. Talbot, ${ }^{*}$ X. Zhao,‡ G. F. Wagner, $\S$ Y. R. Boisclair,\# and P. Lacasse ${ }^{2}$ \\ *Department of Biology, Faculty of Sciences, University of Sherbrooke, Sherbrooke, Quebec, Canada, J1K 2R1 \\ †Dairy and Swine Research and Development Centre, Agriculture and Agri-Food Canada, PO Box 90, STN Lennoxville, Sherbrooke, Quebec, \\ Canada J1M 1 Z3 \\ ‡Department of Animal Science, McGill University, Ste. Anne de Bellevue, Quebec, Canada, H9X 3V9 \\ $\S$ Department of Physiology and Pharmacology, Faculty of Medicine and Dentistry, The University of Western Ontario, London, Ontario, \\ Canada N6A 5C1 \\ \#Department of Animal Science, Cornell University, Ithaca, NY 14853
}

\section{ABSTRACT}

The transition from pregnancy to lactation is marked by metabolic, hormonal, and immunological changes that have an impact on the incidence of infectious and metabolic diseases. The aim of this study was to evaluate the effect on immune function and blood metabolite concentration of limiting milk production in early lactation to reduce negative energy balance. Twenty-two multiparous Holstein cows were milked either once a day $(1 \times)$ or twice a day $(2 \times)$ for the first week postpartum. All cows were milked twice daily for the rest of lactation. Blood concentrations of nonesterified fatty acids (NEFA), $\beta$-hydroxybutyric acid (BHBA), calcium, bilirubin, urea, phosphorus, glucose, leptin, stanniocalcin-1, and $17 \beta$-estradiol were determined in samples collected from $5 \mathrm{wk}$ before scheduled calving to 5 wk after calving. Polymorphonuclear leukocytes (PMNL) were isolated from blood to conduct assays for chemotaxis, phagocytosis, and respiratory burst. Peripheral blood mononuclear cells (PBMC) were isolated to evaluate lymphocyte proliferation and cytokine production (tumor necrosis factor- $\alpha$, IL-4, and interferon- $\gamma$ ). Cows milked $1 \times$ produced $31 \%$ less milk than cows milked $2 \times$ during the first week of lactation. Over the following 13 wk of lactation, the milk production of cows milked $1 \times$ during the first week was $8.1 \%$ lower than for cows milked $2 \times$. However, because the percentages of fat and protein were greater in the milk from $1 \times$ cows, the yields of milk components and energy-corrected milk were similar. Calving induced an increase in the concentrations of NEFA, BHBA, urea, and bilirubin. The increases in levels of NEFA and BHBA were greater in cows milked $2 \times$ than in cows

\footnotetext{
Received May 27, 2008.

Accepted December 23, 2008.

${ }^{1}$ Dairy and Swine Research and Development Centre contribution no. 984 .

${ }^{2}$ Corresponding author: lacassep@agr.gc.ca
}

milked $1 \times$. During the same period, the serum glucose concentration decreased but remained greater in cows milked $1 \times$. Serum calcium on $\mathrm{d} 4$ and serum phosphorus on $\mathrm{d} 4$ and 5 were greater in cows milked $1 \times$. The differences between the 2 groups persisted beyond treatment until postpartum d 24 for NEFA and glucose and until postpartum d 14 for BHBA. After calving, the concentrations of leptin and stanniocalcin-1 decreased. During the first week postpartum, the decrease of leptin was less marked in cows milked $1 \times$. The immune functions of PBMC and PMNL isolated from experimental cows and incubated using a standard medium did not show clear-cut peripartum immunosuppression. These variables were not significantly affected by the treatments, with the exception of interferon- $\gamma$ secretion, which was greater on $\mathrm{d} 5$ and 14 in cows milked $1 \times$. In conclusion, limiting milk production in early lactation had positive effects on metabolite concentration, but larger studies are necessary to establish if this could reduce disease incidence.

Key words: immune function, leptin, stanniocalcin-1, transition period

\section{INTRODUCTION}

The transition period, defined as 3 wk prepartum to 3 wk postpartum, is critical for a cow's health. This period is marked by nutritional, metabolic, hormonal, and immunological changes that have an impact on the incidence of infections and metabolic diseases. The nutrition of periparturient cows is characterized by requirements that exceed their dietary intake potential. This results in a temporary state of negative energy balance (NEB), during which blood glucose decreases and body tissue reserves are mobilized to provide additional energy, leading to elevated plasma NEFA and BHBA (Drackley, 1999; Busato et al., 2002; Goff et al., 2002; Accorsi et al., 2005). This period is also marked by a decrease in the concentrations of blood calcium and phosphorus, which are secreted in colostrum and 
milk. Levels of estrogens and progesterone are greatly modified during the transition period. Other endocrine changes occur during this period, and some of them, such as the decrease in leptin concentration, seem to be linked to lipomobilization (Block et al., 2001; Accorsi et al., 2005). All of these metabolic changes can lead to diseases such as hepatic lipidosis, ketosis, and hypocalcemia and can reduce reproductive performance (Goff et al., 2002). Cows with metabolic disturbances or health problems in early lactation produce less milk than healthy cows, resulting in economic losses for dairy farmers (Drackley, 1999).

During the periparturient period, the dairy cow experiences a natural state of immunosuppression, which is associated with a high susceptibility to infectious diseases such as mastitis (Kehrli and Harp, 2001). Parturition in dairy cattle is associated with impairment of PMNL phagocytosis and oxidative burst activity (Kehrli et al., 1989; Hoeben et al., 2000) and with a decrease in the ability to fight bacterial infections. This period is also marked by decreased responsiveness of blood lymphocytes to stimulation with mitogenic agents and by decreased immunoglobulin production by B cells (Nonnecke et al., 2003). Various hypotheses have been put forward that attribute the impairment of immune functions around the time of calving to endocrine or metabolic changes. In vitro, the presence of 17ß-estradiol (E2), NEFA, and BHBA in high concentrations can adversely affect the respiratory burst and the phagocytic capacity of PMNL (Suriyasathaporn et al., 2000; Lamote et al., 2004, 2006; Scalia et al., 2006). The hormone leptin declines at calving in dairy cows and leptin has been reported in rodents to stimulate cytokine production and immune function (Ingvartsen and Boisclair, 2001). It may therefore be implicated in periparturient immunosuppression. Stanniocalcin-1 (STC-1) is another hormone that has been implicated in regulation of the immune response (Kanellis et al., 2004; Chakraborty et al., 2007). Although the variation of the cow's systemic STC-1 in early lactation has not been evaluated, it does vary according to lactation cycle in both rodents and cows (Deol et al., 2000; Tremblay et al., 2009).

In the dairy industry, cows are genetically selected for high milk production. Unfortunately, the greater milk output increases health problems in early lactation by increasing the NEB (Goff and Horst, 1997). Milking frequency is a factor that affects both milk yield and metabolic disturbances around calving (Rémond and Pomiès, 2005). Cows milked 3 times daily had $19 \%$ greater plasma BHBA concentrations and $6 \%$ lower glucose concentrations compared with cows milked twice daily (Andersen et al., 2004). In early lactation, plasma NEFA and BHBA concentrations and milk production are lower in cows milked once daily compared with cows milked 3 times daily (Patton et al., 2006). Therefore, our hypothesis was that reducing the NEB by limiting milk production in early lactation would help to attenuate metabolic disturbances and, at the same time, decrease the magnitude of the periparturient immunosuppression. The objective of this study was to evaluate the effect on immune function and blood metabolite concentration of milking cows once a day during the first week of lactation.

\section{MATERIALS AND METHODS}

\section{Animals and Experimental Procedures}

The experiment was conducted in accordance with the guidelines of the Canadian Council on Animal Care (1993). Twenty-two pregnant multiparous Holstein cows were housed at the Dairy and Swine Research and Development Centre of Agriculture and Agri-Food Canada (Sherbrooke, Quebec, Canada). Half of the animals were milked once daily $(1 \times$ group) at 0600 $\mathrm{h}$ during the first week after calving and twice daily $(0700$ and $1800 \mathrm{~h})$ for the rest of the lactation. The rest of the animals were milked twice daily $(2 \times$ group $)$ for the entire lactation $(0700$ and $1800 \mathrm{~h})$. For the $5 \mathrm{wk}$ preceding calving, cows received $10 \mathrm{~kg} / \mathrm{d}$ of TMR once a day (CP 13.6\%, ADF 17.9\%, NDF 28.6\%, Ca 0.7\%, P $0.5 \%, \mathrm{Mg} 0.8 \%$, and $\mathrm{K} 1.2 \%$ ) and hay twice a day (CP $7.8 \%$, ADF $37.4 \%$, NDF $62.7 \%$, Ca $0.2 \%$, P $0.2 \%, \mathrm{Mg}$ $0.1 \%$, and $\mathrm{K} 1.9 \%$ ). After calving, cows were fed with a TMR (CP 15.8\%, ADF 16.2\%, NDF $25.6 \%$, Ca $0.7 \%$, $\mathrm{P} 0.5 \%, \mathrm{Mg} 0.3 \%$, and $\mathrm{K} 1.5 \%$ ) twice a day and $1.5 \mathrm{~kg}$ of hay once a day. During the postpartum period the TMR was offered ad libitum. Feed samples were taken every week and pooled by groups of 4 wk for chemical composition analysis. Feed intake was quantified daily and cows were given free access to fresh water. All the cows were exposed to a photoperiod of $15 \mathrm{~h}$ of light and $9 \mathrm{~h}$ of darkness. Milk production was recorded daily and the cows were weighed 5 wk before calving, at calving, and each week after parturition throughout the experimental period. The concentrations of lactose, protein, fat, and SCC in milk were determined in a commercial laboratory (Valacta Inc., Ste-Anne-deBellevue, Quebec, Canada). Energy-corrected milk was calculated thus: $\mathrm{ECM}=[$ milk $(\mathrm{kg} / \mathrm{d}) \times 0.327]+[$ fat $(\mathrm{kg} / \mathrm{d}) \times 12.86]+[\operatorname{protein}(\mathrm{kg} / \mathrm{d}) \times 7.65]$ (Dairy Records Management Systems, 2006). Blood samples were collected by jugular venipuncture into tubes containing EDTA and used for isolation of PMNL and peripheral blood mononuclear cells (PBMC) during prepartum wk $-5,-3,-1$ and on postpartum d 2, 5, 9, 14, and 21 . Average $( \pm \mathrm{SD})$ prepartum days for sampling at wk -5 , -3, and -1 were $\mathrm{d}-36 \pm 3.6, \mathrm{~d}-22 \pm 3.5$, and $\mathrm{d}-8$ 
\pm 3.4 for the $1 \times$ group and $\mathrm{d}-39 \pm 4.3, \mathrm{~d}-25 \pm 4.1$ and $\mathrm{d}-11 \pm 4.3$ for the $2 \times$ group. Blood samples were taken by tail venipuncture twice a week ( 5 wk before calving to 5 wk after calving) and each day during the week after calving to collect serum and plasma for the assays of metabolites and hormones. Cows received a subcutaneous injection of $1 \mathrm{mg}$ of ovalbumin on $\mathrm{d} 5$ and 26 after calving. Additional blood samples were collected 9, 16, 21, 34, and 55 d after the first albumin injection to measure antibody production.

Few peripartum diseases were observed: 1 cow experienced metritis $(2 \times$ group) and 8 experienced mastitis ( 3 in $1 \times$ group and 5 in the $2 \times$ group). One case of dystocia $(2 \times$ group) and 1 case of retained placenta $(1 \times$ group $)$ were observed.

\section{Isolation of PBMC}

Peripheral blood was centrifuged at $540 \times g$ for 30 min, and the plasma and the packed red blood cells were discarded. The PBMC were isolated from the buffy coat by gradient centrifugation in Ficoll Paque Plus $(30 \mathrm{~min}$ at $540 \times g$; Amersham Corp., Arlington Heights, IL). The PBMC from the Ficoll gradient were loaded onto a sucrose gradient $(7 \mathrm{~mL}$ of $10 \%$ sucrose and $30 \mathrm{~mL}$ of $20 \%$ sucrose) and centrifuged at $540 \times$ $g$ for $8 \mathrm{~min}$. The supernatant was discarded and the pellet was washed with Hanks' Balanced Salt Solution (HBSS, without $\mathrm{Ca}^{2+}$ and $\mathrm{Mg}^{2+}$, Gibco Laboratories, Grand Island, NY) and centrifuged at $300 \times g$ for 8 min. The red blood cells were lysed with Tris- $\mathrm{NH}_{4} \mathrm{Cl}$. The PBMC were washed with HBSS and resuspended in $2 \mathrm{~mL}$ of RPMI (Gibco) containing $5 \%$ fetal bovine serum (FBS; Invitrogen, Carlsbad, CA) and antibiotics/antimycotic (A5955, Sigma Chemical Co., St. Louis, $\mathrm{MO})$. The viable cells were counted with a Bright-Line hemacytometer (Hausser Scientific, Horsham, PA) using trypan blue exclusion methodology.

\section{Isolation of Blood PMNL}

Polymorphonuclear leukocytes were isolated from peripheral blood by centrifugation at $540 \times g$ for 30 min, and the plasma and buffy coat were discarded. The packed red blood cells were lysed with Tris$\mathrm{NH}_{4} \mathrm{Cl}$ twice and centrifuged at $210 \times g$ for $5 \mathrm{~min}$. The supernatant was discarded and the PMNL were washed with $45 \mathrm{~mL}$ of HBSS and centrifuged. The PMNL were resuspended in $2 \mathrm{~mL}$ of RPMI preheated to $37^{\circ} \mathrm{C}$. The cells were counted with a Bright-Line hemacytometer.

\section{Proliferation of PBMC}

The proliferation of PBMC was determined by flow cytometric analysis of CFDA-SE (carboxyfluorescein diacetate, succinimidyl ester) staining (Tesfa and Kern, 2003). The PBMC were adjusted to a concentration of 2 $\times 10^{7}$ cells $/ \mathrm{mL}$ in $37^{\circ} \mathrm{C}$ preheated HBSS with $0.2 \mathrm{mM}$ of the fluorophore CFDA-SE (Molecular Probes, Eugene, $\mathrm{OR}$ ) and then incubated at $37^{\circ} \mathrm{C}$ in a water-saturated $5 \% \mathrm{CO}_{2}$ atmosphere for $15 \mathrm{~min}$. Then, the cells were centrifuged at $300 \times g$ for $5 \mathrm{~min}$ and resuspended in $11 \mathrm{~mL}$ of cold RPMI containing 5\% FBS and antibiotics/antimycotic; cells were then incubated at room temperature for $15 \mathrm{~min}$ in the dark. The PMBC were centrifuged again and resuspended in RPMI (Gibco) containing 5\% FBS and antibiotics/antimycotic. The cells were then aliquoted into the wells of a 6 -well plate (3.5 $\mathrm{mL}$ and $5 \times 10^{6}$ cells per well). The PBMC (2 wells) were incubated with the mitogen concanavalin A (Sigma) at a final concentration of $1 \mu \mathrm{g} / \mathrm{mL}$ at $37^{\circ} \mathrm{C}$ in a water-saturated $5 \% \mathrm{CO}_{2}$ atmosphere for $3.5 \mathrm{~d}$. As a negative control, PBMC were incubated without concanavalin A. The cells were subsequently centrifuged at $300 \times g$ for 5 min and resuspended in PBS containing $0.5 \%$ formaldehyde, and the proliferation of PMBC was analyzed by flow cytometry (excitation and emission wavelengths: 492 and $517 \mathrm{~nm}$ ) on a Coulter Epics XL-MCL flow cytometer (Beckman Coulter, Fullerton, CA).

\section{Cytokine Production}

To evaluate tumor necrosis factor- $\alpha$ (TNF- $\alpha)$ production, PBMC were distributed in 24-well plates at a density of $1 \times 10^{7}$ cells $/ \mathrm{mL}$. Phorbol 12-myristate 13-acetate (PMA, Calbiochem, La Jolla, CA) at final concentration of $10 \mu \mathrm{g} / \mathrm{mL}$ and $\mathrm{Ca}^{2+}$ ionophore (ionomycin from Streptomyces conglobatus, Sigma) at final concentration of $100 \mu \mathrm{g} / \mathrm{mL}$ were added, and the PBMC were incubated for $24 \mathrm{~h}$ at $37^{\circ} \mathrm{C}$. For the determination of IL- 4 and IFN- $\gamma, 1 \mathrm{~mL}$ of the supernatant from PBMC stimulated with concanavalin A was recovered $24 \mathrm{~h}$ after incubation. Supernatant cytokine content was determined with commercial kits (Endogen, Rockford, IL).

\section{Phagocytosis Assay}

The PMNL were centrifuged at $1,700 \times g$ for $5 \mathrm{~min}$ and resuspended at a concentration of $1 \times 10^{7}$ cells $/ \mathrm{mL}$ in Krebs' Ringer PBS. The PMNL were distributed in 2 tubes, each containing $1 \times 10^{6}$ cells. Before their utilization, Fluoresbrite YO Carboxylate Microspheres (6.0 $\mu \mathrm{m}$, Polysciences Inc., Warrington, PA) were opsonized with naive cow serum diluted 1:5 in Krebs' Ringer PBS and incubated for $30 \mathrm{~min}$ at $37^{\circ} \mathrm{C}$. The opsonized microspheres were added to the PMNL and incubated for 30 min: 1 tube was incubated at $37^{\circ} \mathrm{C}$ and the other 
at $4^{\circ} \mathrm{C}$ (control). The reaction was stopped by adding $1.8 \mathrm{~mL}$ of cold PBS. The PMNL were washed 3 times with $1.5 \mathrm{~mL}$ of cold PBS and centrifuged at 1,700 $\times g$ for $5 \mathrm{~min}$. After the final centrifugation, PMNL were resuspended in $500 \mu \mathrm{L}$ of cold PBS and fluorescence was analyzed by flow cytometry (excitation and emission wavelengths: 535 and $570 \mathrm{~nm}$ ) on a Coulter Epics XL-MCL flow cytometer (Beckman Coulter).

\section{Chemotaxis Assay}

Zymosan-activated FBS (ZAS) was prepared as described by Lamote et al. (2004). Before use, the ZAS was diluted 1:5 with HBSS and filtered through a 0.22$\mu \mathrm{m}$ filter.

A micropore Transwell Permeable Support was used to assess the chemotaxis of PMNL (12-mm diameter, $3-\mu \mathrm{m}$ pore size; Corning Costar 3462, Oneonta, NY). To perform the assay, cells were adjusted to $1 \times 10^{7}$ PMNL/mL in PBS. Two hundred microliters of PMNL suspension was added to the upper chambers and 400 $\mu \mathrm{L}$ of ZAS was placed in the lower chambers. For the negative control, $400 \mu \mathrm{L}$ of HBSS was used in the lower chamber. After incubation for $90 \mathrm{~min}$ at $37^{\circ} \mathrm{C}$ in a watersaturated $5 \% \mathrm{CO}_{2}$ atmosphere, migrated PMNL were counted with a Bright-Line hemacytometer. Results were expressed as the percentage of cells that migrated through the membrane. Each assay was performed in duplicate.

\section{Respiratory Burst Activity Assay}

Reactive oxygen species production by PMNL was quantified after stimulation of the cells with PMA. Cell preparation $\left(100 \mu \mathrm{L}\right.$ of $10^{7}$ cells $\left./ \mathrm{mL}\right), 60 \mu \mathrm{L}$ of $1 \mathrm{mM}$ luminol (5-amino-2,3-dihydro-1,4-phthalazinedione, stock solution in dimethyl sulfoxide; Sigma), and 20 $\mu \mathrm{L}$ of $0.2 \mu \mathrm{g} / \mathrm{mL}$ PMA (stock solution in dimethyl sulfoxide; EMD, Darmstadt, Germany) were added to $220 \mu \mathrm{L}$ of preheated $\left(37^{\circ} \mathrm{C}\right) \mathrm{RPMI}$ without phenol red. The measurement of $\mathrm{H}_{2} \mathrm{O}_{2}$ release was monitored using a Modulus Single Tube Luminometer (Turner Biosystems, Sunnyvale, CA) in duplicate over a period of 30 min at $37^{\circ} \mathrm{C}$ with acquisition every $10 \mathrm{~s}$. A negative control was performed by replacing the PMA solution with an equivalent volume of dimethyl sulfoxide. The area under the curve was calculated over a period of 30 min with SAS software (SAS Institute, Cary, NC).

\section{Ovalbumin Antibody}

To evaluate antibody production during the peripartum period, the animals received a subcutaneous injection of $1 \mathrm{~mL}$ of ovalbumin antigen (Sigma; final concentration of $1 \mathrm{mg} / \mathrm{mL}$ ) with $1 \mathrm{~mL}$ of incomplete
Freund's adjuvant (Sigma) on d 5 and d 26 after calving. Blood samples were collected from the animals twice a week during the experiment and serum was frozen at $-20^{\circ} \mathrm{C}$ until analyzed. Ovalbumin antibody titer was determined by ELISA. Briefly, 96-well microplates were coated with $5 \mu \mathrm{g} / \mathrm{mL}$ ovalbumin. Serial dilutions $(1: 2)$ of the sera were loaded on the microplates. Antibody against ovalbumin was detected with peroxidasecomplexed goat antibody against bovine IgG (Jackson Immunoresearch, West Grove, PA, diluted at 1:10,000). Peroxidase activity was detected with tetramethyl benzidine (TMB) reagent (KPL, Gaithersburg, MD) according to the manufacturer's recommendations.

\section{Hormone Assays}

The serum concentration of E2 was determined by RIA using the approach described by Delbecchi and Lacasse (2006). The serum concentration of STC-1 was determined by RIA as described by Niu et al. (2000). The plasma leptin concentrations were determined by RIA as described by Ehrhardt et al. (2000).

\section{Metabolite Assays}

Plasma urea was determined using a BUN commercial kit (Diagnostic Chemicals Ltd., Charlottetown, Prince Edward Island, Canada), and absorption was monitored using a Pharmacia Biotech Ultrospec-3000 spectrophotometer (Pharmacia Biotech, London, UK). Bilirubin was determined in a commercial laboratory (BioVet, St-Hyacinthe, Quebec, Canada). Serum calcium was determined by using the QuantiChrom Calcium Assay Kit (BioAssay Systems, Hayward, CA). Serum BHBA was evaluated with the $\beta$-hydroxybutyrate reagent kit (Pointe Scientific Inc., Canton, MI). Serum phosphorus was determined with the Phosphorus-SL assay (Diagnostic Chemicals Ltd.).

Plasma NEFA was determined with the NEFA-HR-2 kit (Wako, Richmond, VA), following the manufacturer's protocol modified to accommodate a 96-well microplate. Briefly, reagents A and B were prepared as described in the protocol. Five standards were prepared from the supplied stock. The samples, standards, and blanks were added in duplicate at $10 \mu \mathrm{L}$ per well. Then, $100 \mu \mathrm{L}$ of reagent $\mathrm{A}$ was added and incubated for 30 min. Finally, $200 \mu \mathrm{L}$ of reagent B was added and incubated for an additional $30 \mathrm{~min}$ and then the plate was read at $550 \mathrm{~nm}$ using a SpectraMAX 250 microplate reader (Molecular Devices Co., Sunnydale, CA).

Plasma glucose was determined with the GLU Roche/Hitachi kit by following a modified version of the manufacturer's protocol to accommodate a 96-well microplate (Roche Diagnostics, Indianapolis, IN). For 


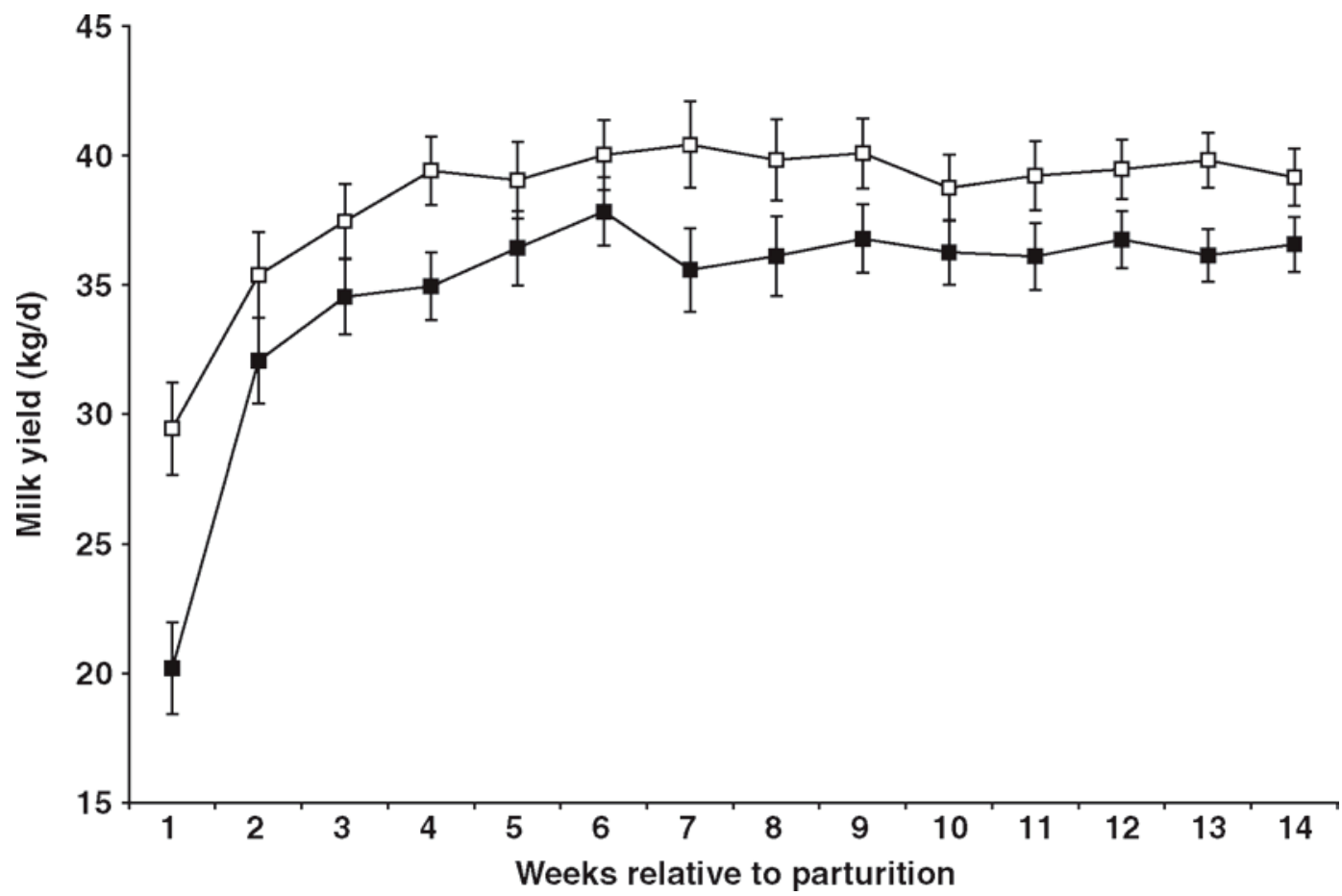

Figure 1. Effect of milking frequency during the first week of lactation on daily milk production over the first 14 wk of lactation. $\mathbf{\square}=$ cows milked once daily during the first week of lactation and then twice daily for the rest of lactation; $\square=$ cows milked twice daily throughout lactation. Milk production was lower $(P<0.002)$ during wk 1 and tended to be lower $(P=0.06)$ during wk 2 to 14 in cows milked once daily. Data are presented as least squares means $\pm \mathrm{SEM}$.

the glucose assay, $200 \mu \mathrm{L}$ of GOD-PAP reagent from the kit was added to $10 \mu \mathrm{L}$ of plasma sample and read at $510 \mathrm{~nm}$ on a Spectra Max 250 microplate reader (Molecular Devices Co.).

\section{Statistical Analysis}

Data were analyzed separately for the prepartum period, the treatment period (the week following calving), and wk 2 to 14 of lactation. Because measurements made before calving were not made at fixed times (calving time is not precisely predictable), data were analyzed using time as a regression variable. Postcalving data were analyzed as repeated measurements using the MIXED procedure of SAS with spatial power as the covariance structure. For DMI, a global analysis was performed over the 3 periods using the MIXED procedure of SAS with spatial power as the covariance structure. The weekly increase in DMI in early lactation was calculated and analyzed with PROC MIXED. Evolution of immune parameters across time was determined by averaging the data by periods (precalving, treatment, and posttreatment) and analyzed using the MIXED procedure of SAS. Cytokine production was analyzed using the GLIMMIX procedure with the Gamma distribution function (SAS Institute).

\section{RESULTS}

\section{Milk Production, DMI, and BW Change}

During the first week of lactation, cows milked $1 \times$ produced $31 \%$ less milk (20.2 vs. $29.4 \mathrm{~kg} / \mathrm{d} ; P<0.002)$ than cows milked $2 \times$ (Figure 1 ). Over the next $13 \mathrm{wk}$ of lactation, the daily milk production of cows milked $1 \times$ during the first week was $3.2 \mathrm{~kg}(8.1 \%)$ lower $(P=$ $0.06)$ than that of cows milked $2 \times$.

No difference was observed in the percentage of fat, protein, lactose, and SCC between the 2 groups during the first week of lactation (Table 1$)$. However, fat $(P$ $<0.05)$ and protein $(P<0.05)$ contents of milk were greater in cows milked $1 \times$ during the posttreatment period. Consequently, fat, protein, and lactose yields were similar for both groups during the posttreatment period (Table 1). Accordingly, posttreatment ECM was similar $(P>0.15)$ in both groups, averaging 37.0 and $37.6 \mathrm{~kg} / \mathrm{d}$ for $1 \times$ and $2 \times$ milked cows, respectively.

No difference in DMI was found between the 2 groups during the experimental period, except that between wk 1 and 2, the increase in DMI was faster in the group milked $1 \times(P<0.01$; data not shown $)$ than in that milked $2 \times$. During the experimental period, BCS did not vary as a function of milking frequency (data not shown) but the early-lactation BW loss was less in cows 

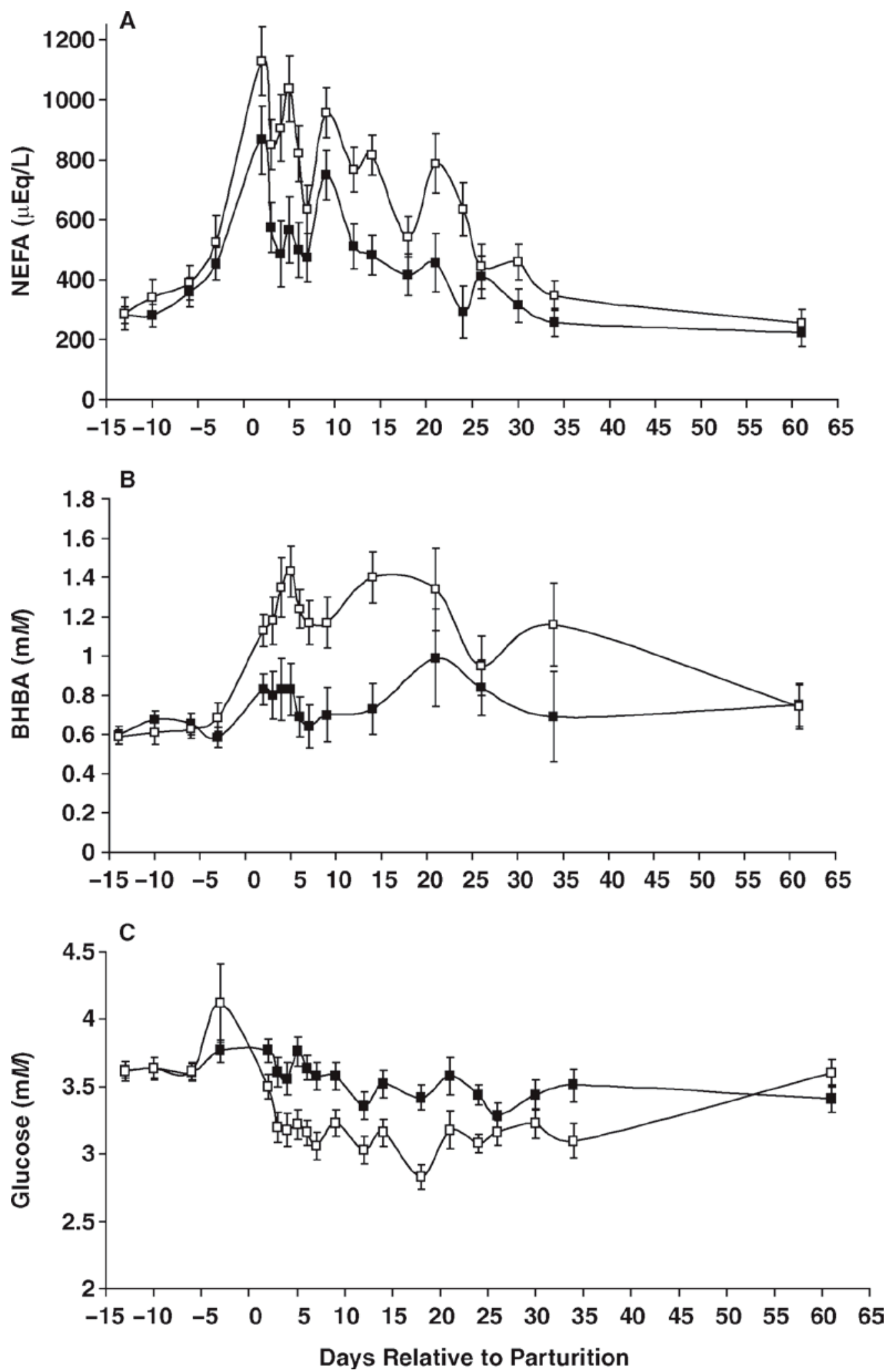

Figure 2. Effect of milking frequency during the first week of lactation on serum NEFA (A), BHBA (B), and glucose (C) concentration in relation to the days around parturition. $\mathbf{\square}=$ cows milked once daily during the first week of lactation and then twice daily for the rest of lactation; $\square=$ cows milked twice daily throughout lactation. The postpartum differences between the 2 groups were significant $(P<0.05)$ until $\mathrm{d}$ 24 for NEFA and glucose, and until d 14 for BHBA. Data before calving are presented as means \pm SEM and data after calving are presented as least squares means \pm SEM. 
Table 1. Milk composition of cows milked once $(1 \times)$ or twice $(2 \times)$ daily during the first week of lactation and then twice daily for the rest of lactation

\begin{tabular}{|c|c|c|c|c|c|c|}
\hline \multirow[b]{2}{*}{ Composition } & \multicolumn{3}{|c|}{ Wk 1 of lactation } & \multicolumn{3}{|c|}{ Wk 2 to 14 of lactation } \\
\hline & $1 \times$ & $2 \times$ & $P$-value & $1 \times$ & $2 \times$ & $P$-value \\
\hline Fat, $\%$ & 4.6 & 4.3 & $\mathrm{NS}^{1}$ & 3.8 & 3.5 & 0.03 \\
\hline Fat, $\mathrm{kg} / \mathrm{d}$ & 0.96 & 1.30 & 0.01 & 1.34 & 1.31 & NS \\
\hline Protein, \% & 3.8 & 3.7 & NS & 3.1 & 2.9 & 0.02 \\
\hline Protein, $\mathrm{kg} / \mathrm{d}$ & 0.87 & 1.14 & 0.01 & 1.08 & 1.10 & NS \\
\hline Lactose, $\%$ & 4.28 & 4.18 & NS & 4.60 & 4.52 & 0.15 \\
\hline Lactose, $\mathrm{kg} / \mathrm{d}$ & 0.92 & 1.24 & 0.01 & 1.61 & 1.71 & NS \\
\hline $\mathrm{SCC}(\times 1,000 / \mathrm{mL})$ & 205.9 & 186.65 & NS & $111.17^{2}$ & $62.76^{2}$ & NS \\
\hline Total SCC $(\times 1,000)$ & 483.23 & 650.49 & NS & $385.08^{2}$ & $236.02^{2}$ & NS \\
\hline
\end{tabular}

milked $1 \times(P<0.01)$, averaging 1.44 and $2.59 \mathrm{~kg} / \mathrm{d}$ for $1 \times$ and $2 \times$ cows, respectively.

\section{Blood Metabolites}

Following calving, concentrations of both NEFA and BHBA (Figure 2, panels $\mathrm{A}$ and $\mathrm{B}$ ) were significantly greater in cows milked $2 \times$ compared with $1 \times(P<$ 0.05 and $<0.01$ for NEFA and BHBA, respectively). After parturition, the glucose concentration decreased $(P<0.001)$ in the 2 groups but remained greater $(P$ $<0.001$ ) in cows milked $1 \times$ (Figure 2, panel C). The difference between the 2 groups persisted beyond the treatment period until postpartum d 24 for NEFA and glucose and until postpartum d 14 for BHBA. Serum calcium on $\mathrm{d} 4(P<0.05)$ and serum phosphorus on $\mathrm{d}$ $4(P=0.07)$ and $\mathrm{d} 5(P<0.02)$ were greater in cows milked $1 \times$ (Figure 3, panels A and B). At calving, bilirubin increased $(P<0.001)$ but there was no difference between the 2 experimental groups (data not shown). Plasma urea was greater in cows milked $2 \times$ on $\mathrm{d} 3(4.53$ vs. $5.66 \mathrm{mM} ; P<0.05$; data not shown).

\section{Hormones}

Serum concentrations of E2 increased a few days before calving $(P<0.001)$ and decreased after calving $(P<0.001)$. After parturition, serum E2 on d $4(P<$ $0.05)$, d $5(P<0.02)$, and d $6(P<0.05)$ was greater in cows milked $1 \times$ (data not shown). Concentrations of STC-1 in serum declined $(P<0.01)$ in early lactation (Figure 4; panel A). The concentration of STC-1 was not affected by the treatment $(P>0.15)$. Plasma leptin decreased during the week after calving $(P<0.001)$ and continued to decrease in the following weeks $(P<0.001$; Figure 4, panel B). Leptin concentration was greater in $1 \times$ cows during the treatment period $(P<0.05)$.

\section{Immunological Parameters}

The immune functions of PMNL did not show clearcut peripartum immunosuppression. No differences were observed in chemotaxis (Figure 5, panel A), phagocytosis, or oxidative burst activity over time or between the 2 groups $(P<0.15$; data not shown $)$.

Proliferation of PBMC was lowest during the week after parturition $(P<0.02)$ but no difference was observed between the 2 groups (Figure 5, panel B). Cytokine production by stimulated PBMC decreased after calving $(P<0.05)$. The release of IFN- $\gamma$ was greater in cows milked $1 \times$ on $\mathrm{d} 5(P<0.02)$ and $\mathrm{d} 14(P<$ 0.01 ; Figure 6, panel A). Although the release of IL-4 increased in the posttreatment period $(P<0.01)$, no treatment effect was found (Figure 6, panel B). At calving, the production of TNF- $\alpha$ by stimulated PBMC increased $(P<0.05)$ and then declined afterward (Figure 6 , panel $\mathrm{C}$ ). No treatment effect on TNF- $\alpha$ production was noted.

A low level of antibody production was observed after the first injection of ovalbumin, on $\mathrm{d} 5$, but a greater response was observed after the second injection, on $\mathrm{d}$ 26 . Ovalbumin antibody production profiles were similar for both groups $(P>0.25$; data not shown $)$.

\section{DISCUSSION}

In this study, the effect of once-daily milking during the first week of lactation was examined in relation to milk production, blood metabolites, and immunological parameters in dairy cows. Our hypothesis was that a reduction in milk production in early lactation would decrease the magnitude of NEB and have a positive effect on animal health. In general, milking $1 \times$ did not pose problems in terms of routine management of the cattle. Results showed that the reduction (around 30\%) in milk yield during the treatment was similar to that found in previous studies (Rémond and Pomiès, 2005).

In our experiment, we found that milk production tended to be less even after a return to twice-daily milking. Hale et al. (2003) reported that increasing milking to 4 times a day during the first 3 wk of lactation increases milk production for the first 6 mo of 

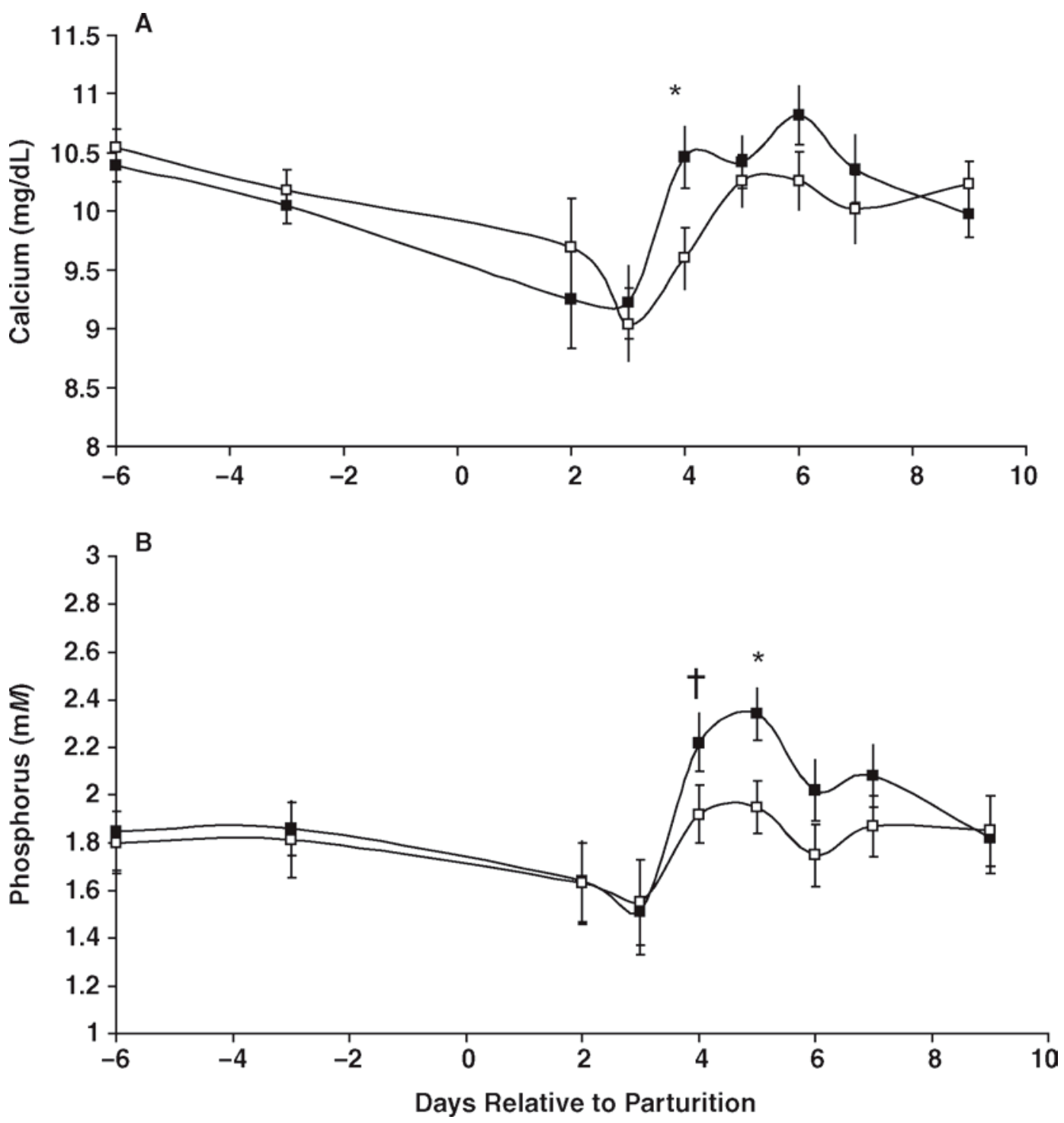

Figure 3. Effect of milking frequency during the first week of lactation on serum calcium (A) and phosphorus (B) concentration in relation to the days around parturition. $\mathbf{\square}=$ cows milked once daily during the first week of lactation and then twice daily for the rest of lactation; $\square=$ cows milked twice daily throughout lactation. Time points with significant difference are denoted with $*(P<0.05)$ or $\dagger(P<0.1)$. Data before calving are presented as means \pm SEM and data after calving are presented as least squares means \pm SEM.

lactation. However, the reduction in milk production was completely compensated by an increase in the concentration of milk components, and the yields of protein, fat, lactose, and ECM were similar. Accordingly, Hale et al. (2003) and Fernandez et al. (2004) reported that milking 4 times a day in early lactation reduced subsequent milk fat and protein content, so that the yields of milk fat and protein did not differ.

In our study, reduced milking frequency in early lactation led to a decrease in metabolic imbalances as reflected in findings similar to those described previously (Patton et al., 2006). Accordingly, an increase in milking frequency in early lactation has been reported to accentuate metabolic imbalances (Andersen et al.,
2004; Fernandez et al., 2004). As expected, NEFA and BHBA blood concentrations increased after calving. The concentrations of NEFA and BHBA provide an indication of fat mobilization, and NEFA is often used as an indicator of NEB. The NEFA and BHBA profiles differed between cows milked $1 \times$ and those milked $2 \times$. The blood concentrations of NEFA and BHBA were lower in cows milked $1 \times$ and stayed lower even after the switch to twice-daily milking was made in the second week of lactation. The fact that the urea level was transiently lower in $1 \times$ cows is also indicative of a lower need to use amino acid for gluconeogenesis in these animals. These results show that reducing milking frequency during the transition period contributes 


\section{A}

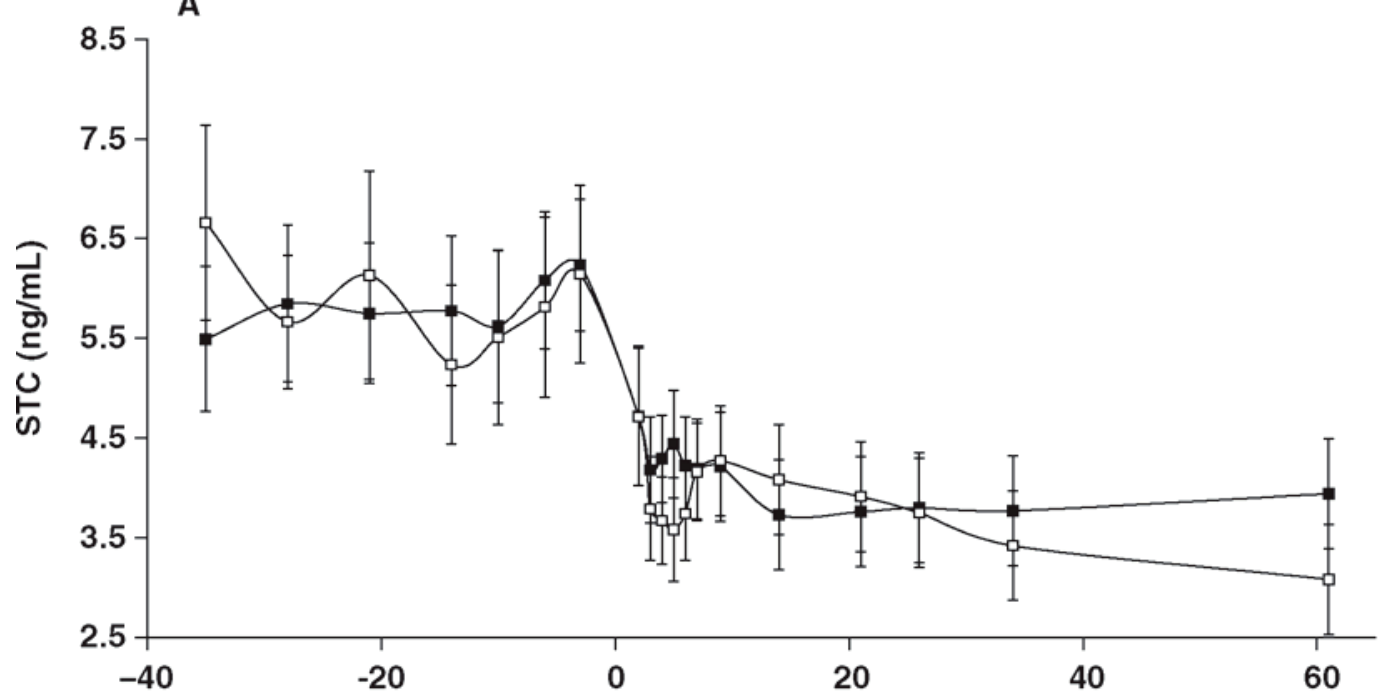

B

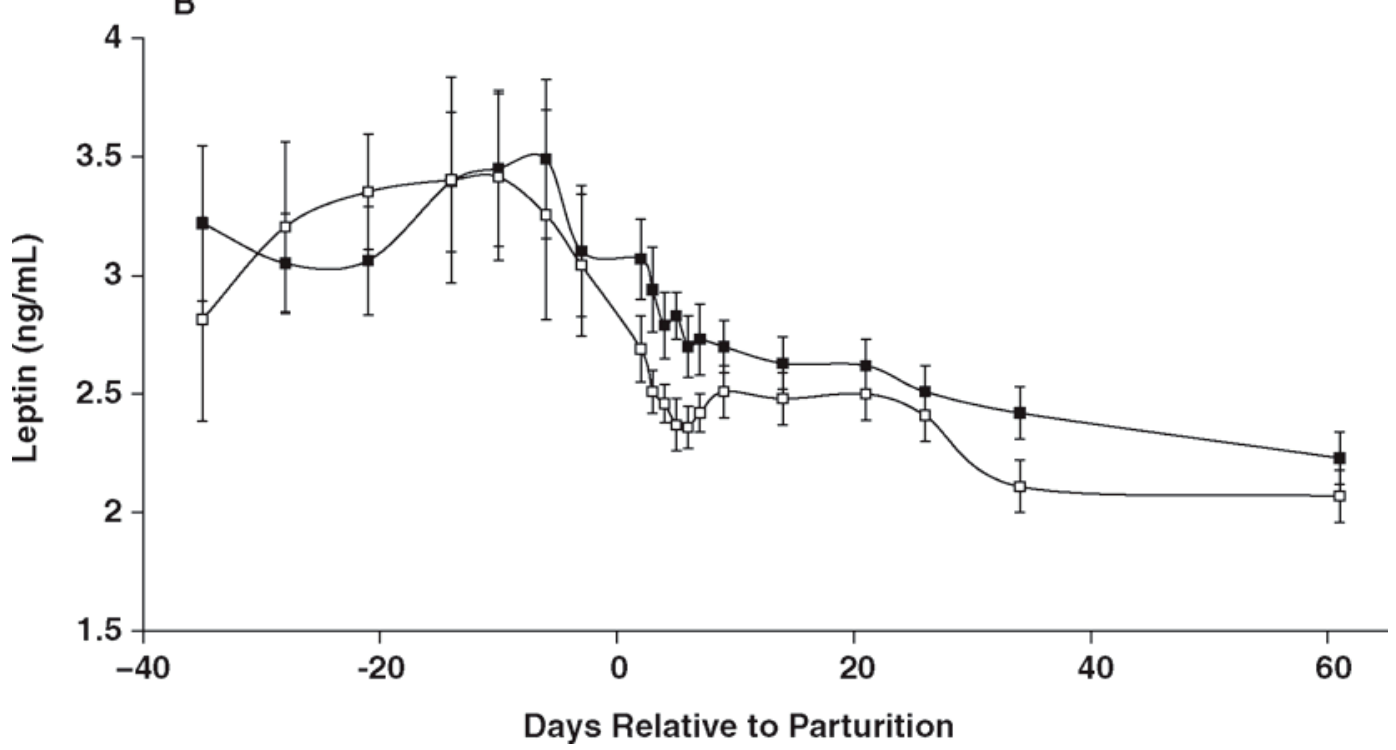

Figure 4. Effect of milking frequency during the first week of lactation on serum stanniocalcin (A) and leptin (B) concentration in relation to the days around parturition. = cows milked once daily $(1 \times)$ during the first week of lactation and then twice daily for the rest of lactation; $\square=$ cows milked twice daily throughout lactation. Leptin concentration was greater in $1 \times$ cows during the treatment period $(P<0.05)$. Data before calving are presented as means \pm SEM and data after calving are presented as least squares means \pm SEM.

to a better energy balance that persists beyond the treatment period.

In ruminants, plasma glucose is derived almost exclusively from gluconeogenesis. Around calving, plasma glucose concentrations decrease because of the high energy demands associated with milking and the harnessing of glucose for the production of lactose. Low glucose levels can also be a consequence of decreased appetite and impaired liver function (Drackley et al., 2001). In our study, the plasma glucose concentration was greater in cows milked $1 \times$, a result that is consistent with the positive effects observed on energy status and metabolite profiles. The glucose concentration in cows milked $1 \times$ remained higher even after the treatment period. Ketone bodies are known to impair gluconeogenesis (Goff and Horst, 1997). Therefore, these cows have greater glucose levels, probably because of their lower milk production, lower fat mobilization, and increased gluconeogenesis.

Serum concentrations of phosphorus and calcium were slightly greater in $1 \times$ cows during the first week of lactation. Calcium and phosphorus are both present in milk. During the first week of lactation, the calcium and the phosphorus concentrations decreased for a few days because of the adaptation required to meet the high demand for milk production. None of our cows 


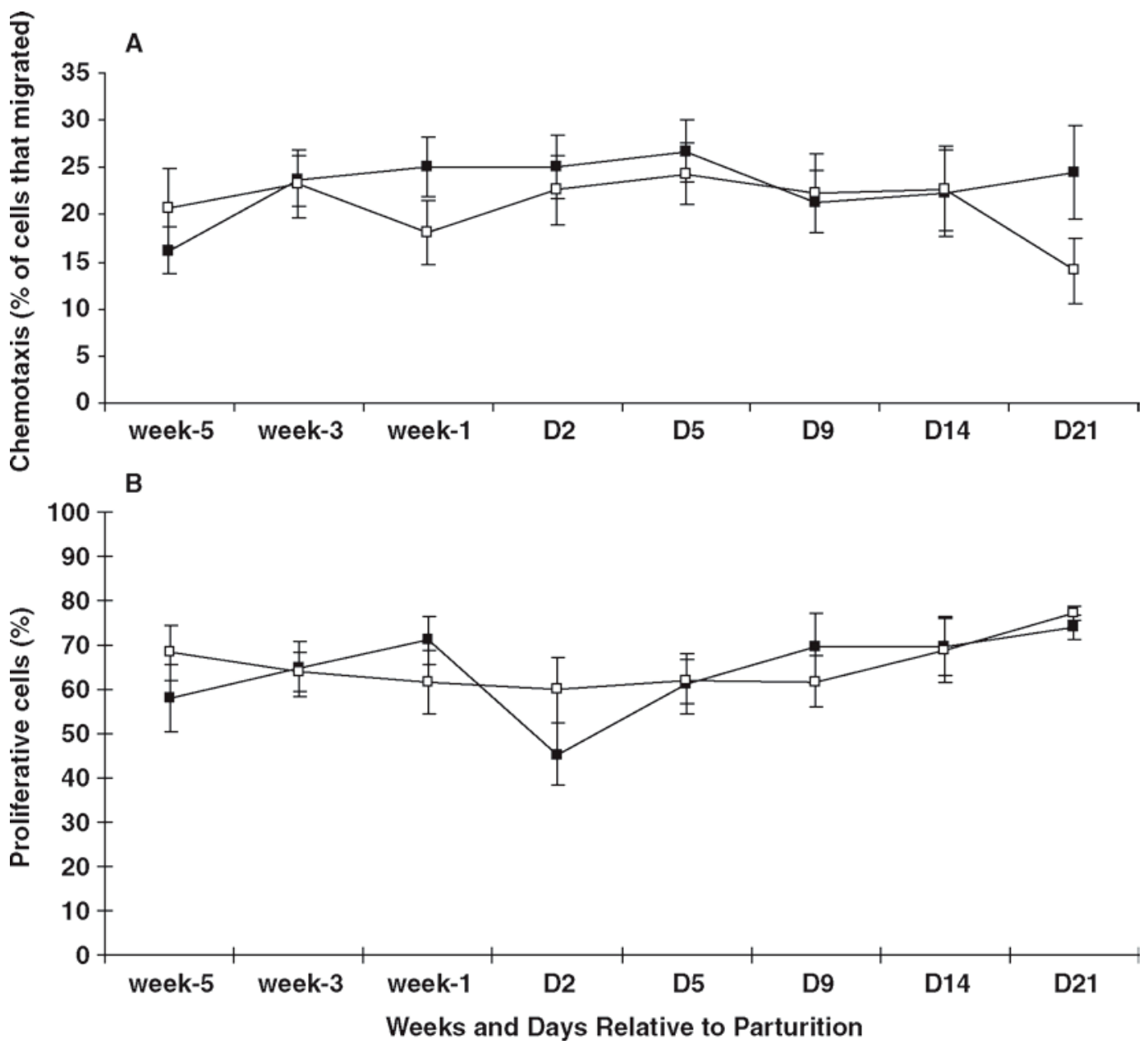

Figure 5. Effect of milking frequency during the first week of lactation on blood PMNL chemotaxis (A) and peripheral blood mononuclear cells proliferation (B) in relation to weeks and days around parturition. $\mathbf{a}=$ cows milked once daily during the first week of lactation and then twice daily for the rest of lactation; $\square=$ cows milked twice daily throughout lactation. Data are presented as means \pm SEM.

experienced clinical hypocalcemia. A larger study would be needed to determine if this gain in calcium and phosphorus is sufficient to reduce the incidence of milk fever.

There was no difference between the DMI of cows milked $1 \times$ and cows milked $2 \times$. However, between wk 1 and 2 of lactation, the increase in DMI was significantly greater for cows milked $1 \times$. High NEFA and BHBA levels cause a decrease in appetite (Ingvartsen and Andersen, 2000) and may have delayed the increase in DMI in $2 \times$ cows. In early lactation, cows milked $1 \times$ have lower blood concentrations of NEFA and BHBA, which can lead to an increase in appetite and contribute to a less negative energy balance. Similarly, the BW loss was reduced in cows milked $1 \times$, reflecting a less negative energy balance.

Plasma leptin has been shown to be negatively correlated with NEFA concentration, and the decrease in leptin around parturition is caused by the NEB (Block et al., 2001). The present study clearly showed that leptin decreased at calving, which is in agreement with the findings of previous studies. During the treatment period, the plasma leptin concentration was greater in cows milked $1 \times$, probably because of their less negative energy balance. In mice, starvation-induced immunosuppression was reversed by exogenous leptin (Lord et al., 1998). The role of leptin in regulation of bovine immune function has not been established, but its implication in the immunosuppression observed in postpartum cows cannot be ruled out.

As previously observed, estrogen levels increased just before calving and then declined (Goff and Horst, 1997). In an earlier study in our laboratory, E2 injections were found to increase the risk of mastitis (Delbecchi et al., 2005). Polymorphonuclear leukocytes have estrogen receptors and in vitro studies reported that E2 decreased their functional properties (Lamote et al., 2004, 2006). We therefore hypothesized that estrogens may play a role in suppressed immunity observed at calving. In our study, the E2 level peaked a few days before calving 

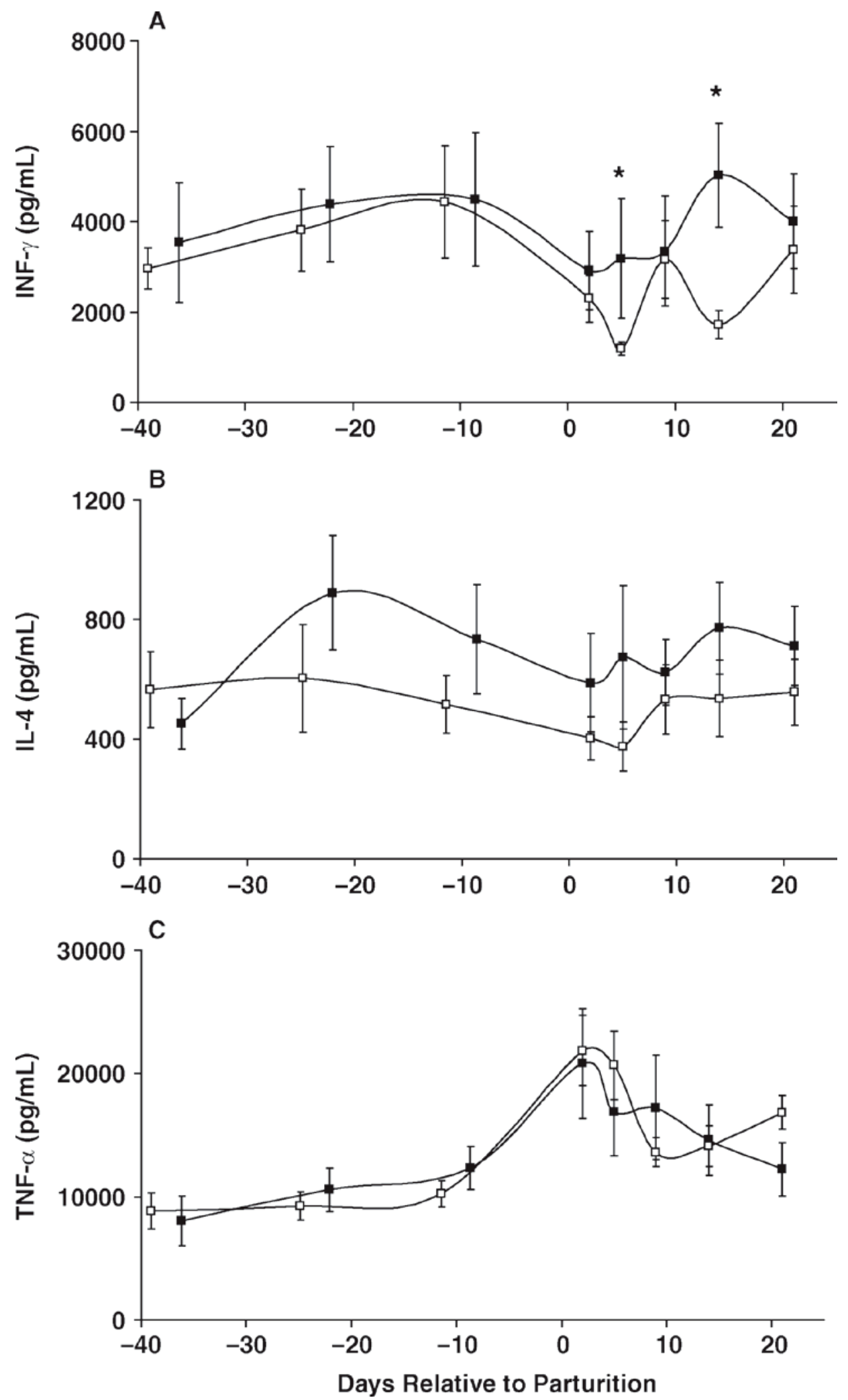

Figure 6. Effect of milking frequency during the first week of lactation on cytokine production: IFN- $\gamma$ (A), IL-4 (B), and tumor necrosis factor- $\alpha(\mathrm{TNF}-\alpha, \mathrm{C})$ by lymphocytes in relation with days around parturition. $\mathbf{\square}=$ cows milked once daily $(1 \times)$ during the first week of lactation and then twice daily for the rest of lactation; $\square=$ cows milked twice daily throughout lactation. Time points with significant difference are denoted with * $(P<0.05)$. Data are presented as means \pm SEM. 
and E2 concentrations did not vary significantly among the cows. After calving, the E2 level declined sharply. Cows milked $1 \times$ had greater blood concentrations of E2 during the treatment period; however, the level was very low and the difference would probably not affect the immune system.

In our study, the STC-1 concentration decreased after calving. This is the first time that peripartum STC-1 concentrations are reported in cows but the profile is similar to that in mice (Deol et al., 2000). In the Delbecchi et al. (2005) study, we observed that estradiol injections increased both milk and serum level of STC-1, as well as increasing the risk of mastitis. In humans, STC-1 inhibits migration of macrophages and T lymphocytes (Kanellis et al., 2004; Chakraborty et al., 2007). As the postpartum level of STC-1 was low and unaffected by treatment, it is unlikely a major component of postcalving immunosuppression. Nevertheless, an effect in late lactation cannot be excluded.

The immunosuppression phenomenon observed at calving appears to be linked to the production of milk. In mastectomized cows, the number of immune cells and their associated functions did not provide clear evidence that calving itself causes immunosuppression (Kimura et al., 1999, 2002; Nonnecke et al., 2003). We therefore hypothesized that reducing milking frequency immediately after parturition would counter immunosuppression. In our study, the immune functions evaluated for PBMC (proliferation and cytokine production) are indicative of a mild immunosuppression around calving. Lymphocyte proliferation under concanavalin A stimulation indicates that there is a slight reduction in lymphocyte activation during the week after calving, but the functions were not significantly affected by the treatment. The production of IL- 4 and TNF- $\alpha$ also provided evidence of immunosuppression but these cytokines were not affected by the treatment. In addition, the PMNL functions that were evaluated did not show a clear-cut immunosuppressive state. The causes of immunosuppression in early lactation are not known. In vitro studies have shown that the addition of NEFA, BHBA, and E2 have a negative effect on the cows' immune cells (Suriyasathaporn et al., 2000; Lamote et al., 2004, 2006; Scalia et al., 2006). In our study, the immune cells isolated from the cows' blood were incubated in FBS-supplemented medium. Conversely, when PBMC from mid-lactation cows were incubated with serum from cows of this experiment, the immunosuppressive effects were observed (C. Ster, M. C. Loiselle, and P. Lacasse; unpublished data). These data indicate that the immunosuppression relates to the metabolic milieu of early lactation rather than autonomous immune cell defects.
The production of IFN- $\gamma$ by activated lymphocytes was greater in the lymphocytes of cows milked $1 \times$ after calving. Interferon- $\gamma$ induces an antiviral state that promotes the expression of major histocompatibility complex antigens and enhances the activation of macrophages. In addition, it is important for the development of an effective cell-mediated immune response. Some studies show a decrease in IFN- $\gamma$ production during the postpartum period (Ametaj et al., 2000). In the study by Nonnecke et al. (2003), the IFN- $\gamma$ response was maintained in cows where the mammary gland was removed. This supports our finding that a reduction in milk production attenuates the decrease of IFN- $\gamma$ around calving. In vitro, the presence of NEFA was shown to decrease the production of IFN- $\gamma$ (Lacetera et al., 2003). In our study conducted ex vivo, the blood concentration of NEFA was lower in cows milked $1 \times$, which suggests a persisting effect of NEFA on the ex vivo ability of lymphocytes to produce IFN- $\gamma$.

The transition from pregnancy to lactation is marked by metabolic changes that have an effect on animal health. These metabolic changes relate to the mobilization of reserves to enable milk production. In nature, the quantity of milk needed for offspring increases over time but is relatively low during the newborn's first days of life. This explains the gradual transition from the dry period to a situation of high milk demand, which helps to reduce the magnitude of the NEB. In this experiment we tested an approach that limits milk production by reducing milking frequency. The results indicate that this approach was successful in limiting metabolite imbalances in early lactation. Larger studies are needed to determine whether these positive effects lead to better animal health.

\section{ACKNOWLEDGMENTS}

This research was financially supported by the Dairy Farmers of Canada, Agriculture and Agri-Food Canada, The Canadian Institutes of Health Research, and the Natural Science and Engineering Research Council of Canada. The authors thank several people from the Dairy and Swine R\&D Centre including the technical assistants (Lisette St-James, Étienne Quintal, and Audrey Ballan), the barn staff, and Steve Méthot, who performed the statistical analysis.

\section{REFERENCES}

Accorsi, P. A., N. Govini, R. Gaiani, C. Pezzi, E. Seren, and C. Tamanini. 2005. Leptin, GH, PRL, insulin and metabolic parameters throughout the dry period and lactation in dairy cows. Reprod. Domest. Anim. 40:217-223.

Ametaj, B. N., B. J. Nonnecke, R. L. Horst, and D. C. Beitz. 2000 Effects of retinoic acid and 1,25-dihydroxyvitamin D3 on IFN- 
gamma secretion by mononuclear leukocytes from nulliparous and postparturient dairy cattle. Int. J. Vitam. Nutr. Res. 70:92-101.

Andersen, J. B., N. C. Friggens, T. Larsen, M. Vestergaard, and K. L. Ingvartsen. 2004. Effect of energy density in the diet and milking frequency on plasma metabolites and hormones in early lactation dairy cows. J. Vet. Med. A Physiol. Pathol. Clin. Med. 51:5257.

Block, S. S., W. R. Butler, R. A. Ehrhardt, A. W. Bell, M. E. Van Amburgh, and Y. R. Boisclair. 2001. Decreased concentration of plasma leptin in periparturient dairy cows is caused by negative energy balance. J. Endocrinol. 171:339-348.

Busato, A., D. Faissler, U. Küpfer, and J. W. Blum. 2002. Body condition scores in dairy cows: Associations with metabolic and endocrine changes in healthy dairy cows. J. Vet. Med. 49:455460 .

Canadian Council on Animal Care. 1993. Guide to the Care and Use of Experimental Animals. Vol. 1. 2nd ed. Canadian Council on Animal Care, Ottawa, Ontario, Canada.

Chakraborty, A., H. Brooks, P. Zhang, W. Smith, M. R. McReynolds, J. B. Hoying, R. Bick, L. Truong, B. Poindexter, H. Lan, W. Elbjeirami, and D. Sheikh-Hamad. 2007. Stanniocalcin-1 regulates endothelial gene expression and modulates transendothelial migration of leukocytes. Am. J. Physiol. Renal Physiol. 292:F895F904.

Dairy Records Management Systems. 2006. DHI Glossary. http:// www.drms.org/PDF/materials/glossary.pdf Accessed November $28,2007$.

Delbecchi, L., and P. Lacasse. 2006. Short communication: Suppression of estrous cycles in lactating cows has no effect on milk production. J. Dairy Sci. 89:636-639.

Delbecchi, L., N. Miller, C. Prud'homme, D. Petitclerc, G. F. Wagner, and P. Lacasse. 2005. 17 $\beta$-Estradiol reduces milk synthesis and increases stanniocalcin gene expression in the mammary gland of lactating cows. Livest. Prod. Sci. 98:57-66.

Deol, H. K., R. Varghese, G. F. Wagner, and G. E. Dimattia. 2000. Dynamic regulation of mouse ovarian stanniocalcin expression during gestation and lactation. Endocrinology 141:3412-3421.

Drackley, J. K. 1999. Biology of dairy cows during the transition period: the final frontier? J. Dairy Sci. 82:2259-2273.

Drackley, J. K., T. R. Overton, and G. N Douglas. 2001. Adaptations of glucose and long-chain fatty acid metabolism in liver of dairy cows during the periparturient period. J. Dairy Sci. 84(E Suppl.):E100-E112.

Ehrhardt, R. A., R. M. Slepetis, M. E. Van Amburgh, J. Siegal-Willot, A. W. Bell, and Y. R. Boisclair. 2000. Development of a specific radioimmunoassay to measure physiological changes of circulating leptin in cattle and sheep. J. Endocrinol. 166:519-528.

Fernandez, J., C. M. Ryan, D. M. Galton, and T. R. Overton. 2004 Effect of milking frequency during early lactation on performance and health of dairy cows. J. Dairy Sci. 82(Suppl. 1):424 (Abstr.)

Goff, J. P., and R. L. Horst. 1997. Physiological changes at parturition and their relationship to metabolic disorders. J. Dairy Sci. 80:1260-1268.

Goff, J. P., K. Kimura, and R. L. Horst. 2002. Effect of mastectomy on milk fever, energy, and vitamins $\mathrm{A}, \mathrm{E}$, and $\beta$-carotene status at parturition. J. Dairy Sci. 85:1427-1436.

Hale, S. A., A. V. Capuco, and R. A. Erdman. 2003. Milk yield and mammary growth effects due to increased milking frequency during early lactation. J. Dairy Sci. 86:2061-2071.

Hoeben, D., E. Monfardini, G. Opsomer, C. Burvenich, H. Dosogne, A. De Kruif, and J. F. Beckers. 2000. Chemiluminescence of bovine polymorphonuclear leucocytes during the periparturient period and relation with metabolic markers and bovine pregnancy-associated glycoprotein. J. Dairy Res. 67:249-259.

Ingvartsen, K. L., and J. B. Andersen. 2000. Integration of metabolism and intake regulation: A review focusing on periparturient animals. J. Dairy Sci. 83:1573-1597.
Ingvartsen, K. L., and Y. R. Boisclair. 2001. Leptin and the regulation of food intake, energy homeostasis and immunity with special focus on the periparturient ruminants. Domest. Anim. Endocrinol. $21: 215-250$.

Kanellis, J., R. Bick, G. Garcia, L. Truong, C. C. Tsao, D. Etemadmoghadam, B. Poindexter, L. Feng, R. J. Johnson, and D. Sheikh-Hamad. 2004. Stanniocalcin-1, an inhibitor of macrophage chemotaxis and chemokinesis. Am. J. Physiol. Renal Physiol. 286:F356-F362.

Kehrli, M. E., and J. A. Harp. 2001. Immunity in the mammary gland. Immunology 17:495-516.

Kehrli, M. E., B. J. Nonnecke, and J. A. Roth. 1989. Alterations in bovine neutrophil function during the periparturient period. Am. J. Vet. Res. 50:207-214.

Kimura, K., J. P. Goff, and M. E. Kehrli Jr. 1999. Effects of the presence of the mammary gland on expression of neutrophil adhesion molecules and myeloperoxidase activity in periparturient dairy cows. J. Dairy Sci. 82:2385-2392.

Kimura, K., J. P. Goff, M. E. Jr Kehrli, J. A. Harp, and B. J. Nonnecke. 2002. Effects of mastectomy on composition of peripheral blood mononuclear cell populations in periparturient dairy cows. J. Dairy Sci. 85:1437-1444.

Lacetera, N., D. Scalia, O. Franci, U. Bernabucci, B. Ronchi, and A. Nardone. 2003. Short communication: Effects of nonesterified fatty acids on lymphocyte function in dairy heifers. J. Dairy Sci. $87: 1012-1014$

Lamote, I., E. Meyer, A. De Ketelaere, L. Duchateau, and C. Burvvenich. 2006. Expression of the estrogen receptor in blood neutrophils of dairy cows during the periparturient period. Theriogenology 65:1082-1098.

Lamote, I., E. Meyer, L. Duchateau, and C. Burvvenich. 2004. Influence of 17ß-estradiol, progesterone, and dexamethasone on diapedesis and viability of bovine blood polymorphonuclear leukocytes. J Dairy Sci. 87:3340-3349.

Lord, G. M., G. Matarese, J. K. Howard, R. J. Baker, S. R. Bloom and R. I. Lechler. 1998. Leptin modulates the T-cell immune responses and reverses starvation-induced immunosuppression. Nature 394:897-901.

Niu, P. D., D. P. Radman, E. M. Jaworski, H. Doel, R. Gentz, J. Su, H. S. Olsen, and G. F. Wagner. 2000. Development of a human stanniocalcin radioimmunoassay: Serum and tissue hormone levels and pharmacokinetics in the rat. Mol. Cell. Endocrinol. 162:131144.

Nonnecke, B. J., K. Kimura, J. P. Goff, and M. E. Kehrli Jr. 2003 Effects of the mammary gland on functional capacities of blood mononuclear leukocyte populations from periparturient cows. J. Dairy Sci. 86:2359-2368.

Patton, J., D. A. Kenny, J. F. Mee, F. P. O'Mara, D. C. Wathes, M. Cook, and J. J. Murphy. 2006. Effect of milking frequency and diet on milk production, energy balance, and reproduction in dairy cows. J. Dairy Sci. 89:1478-1487.

Rémond, B., and D. Pomiès. 2005. Once-daily milking of dairy cows: A review of recent French experiments. Anim. Res. 54:427-442.

Scalia, D., N. Lacetera, U. Bernabucci, K. Demeyere, L. Duchateau, and C. Burvenich. 2006. In vitro effects of nonesterified fatty acid on bovine neutrophils oxidative burst and viability. J. Dairy Sci. $89: 147-154$.

Suriyasathaporn, W., C. Heuer, E. N. Noordhuizen-Stassen, and Y H. Schukken. 2000. Hyperketonemia and the impairment of udder defense: A review. Vet. Res. 31:397-412.

Tesfa, L. H. D. V., and F. Kern. 2003. A protocol for combining proliferation, tetramer staining and intracellular cytokine detection for the flow-cytometric analysis of antigen specific T-cells. J. Biol. Regul. Homeost. Agents 17:366-370.

Tremblay, G., L. Delbecchi, M. C. Loiselle, C. Ster, G. F. Wagner, B. G. Talbot, and P. Lacasse. 2009. Serum levels of stanniocalcin-1 in Holstein heifers and cows. Domest. Anim. Endocrinol. 36:105109. 